\title{
$\beta$-Carotene and $\alpha$-tocopherol concentration and antioxidant status in buccal mucosal cells and plasma after oral supplementation
}

\author{
Jürgen G. Erhardt*, Heidrun Mack, Ulrike Sobeck and Hans K. Biesalski \\ Institute of Biological Chemistry and Nutrition, University of Hohenheim, Fruwirthstrasse 12, 70599 Stuttgart, Germany
}

(Received 22 August 2001 - Revised 7 January 2002 - Accepted 15 January 2002)

\begin{abstract}
The uptake of $\alpha$-tocopherol and $\beta$-carotene and their antioxidative effect in plasma and buccal mucosal cells after oral application in twelve subjects is demonstrated in our study. The effect on the antioxidative status was evaluated using a modified thiobarbituric acid-reactive substance (TBARS) method. As expected, the supplement of $134.2 \mathrm{mg} \alpha$-tocopherol/d and $25 \mathrm{mg} \beta$-carotene/d for $7 \mathrm{~d}$ resulted in a significant increase of $\alpha$-tocopherol and $\beta$-carotene concentration in plasma $(P<0 \cdot 05)$. In buccal mucosal cells, the concentration of $\beta$-carotene increased after supplementation $(P<0.05)$, whereas the concentration of $\alpha$-tocopherol remained constant. A decrease in TBARS $(P<0.05)$ was found in buccal mucosal cells but not in plasma. In conclusion, an uptake of the supplemented antioxidants was detected in plasma and in buccal mucosal cells. There was significant change in $\beta$-carotene concentration and oxidative stress as measured using a modified TBARS test in buccal mucosal cells, but not in the plasma.
\end{abstract}

Buccal mucosal cells: Supplementation: $\alpha$-Tocopherol: $\beta$-Carotene: Thiobarbituric acidreactive substances

Oxidative damage to mucosal cells can lead to squamous metaplastic alterations such as oral leucoplakia, which is considered to be a precancerous lesion. Antioxidants such as $\alpha$-tocopherol and partly $\beta$-carotene are able to interrupt intracellular pathogenic mechanisms and can produce regressions in oral leucoplakia (Stich et al. 1988; Garewal et al. 1990; Toma et al. 1992) or systemic sclerosis (Gabriele et al. 2000). The formation of intracellular reactive oxygen species (ROS) is one of these mechanisms which causes damage to proteins, DNA and membrane lipids. Endogenous antioxidants of the organism such as superoxide dismutase, catalase or glutathione peroxidase are able to inactivate ROS. To support the endogenous antioxidative system dietary-derived exogenous antioxidants such as $\alpha$-tocopherol and to some extent $\beta$-carotene, play a major role (Barth et al. 1997). Direct measurement of antioxidants in plasma only gives indirect evidence for the supply to target tissues shown by Peng et al. (1995). It is therefore more appropriate to evaluate the level of $\alpha$-tocopherol and $\beta$-carotene and in consequence their antioxidative capacity directly in the buccal mucosal cells. These cells are easily available and can therefore serve as a model system for the uptake and distribution of dietary components in target tissue.

Up to now, no systematic measurement including a variable for oxidative stress has been carried out to determine the antioxidative efficacy of supplementary vitamins on the cellular antioxidative defence in buccal mucosal cells.

This present study demonstrates the influence of a shortterm supplement of $\beta$-carotene and $\alpha$-tocopherol and their effect on oxidative status in plasma and buccal mucosal cells. We applied an improved thiobarbituric acid-reactive substance (TBARS) assay (Jentzsch et al. 1996) to determine the oxidative stress in plasma and buccal mucosal cells of twelve healthy volunteers.

\section{Subjects and methods \\ Subjects and study design}

Twelve healthy female volunteers (age 23-30 years, mean BMI 21.5 (SD 1.8)) were selected for the study. Exclusion criteria were chronic or acute illness, pregnancy, smoking and vitamin supplementation. During the study, foods containing high levels of $\alpha$-tocopherol and $\beta$-carotene were excluded from the daily diet. The volunteers received daily doses of $\mathrm{D}$ - $\alpha$-tocopherol (134.2 mg; Hermes, Munich, Germany) and $\beta$-carotene (25 mg; Twardy, Flörsheim, Germany) for 1 week. Prior to supplementation

Abbreviations: BHT, 2,6-di-tert-butyl-p-hydroxytoluene; ROS, reactive oxygen species; TBARS, thiobarbituric acid-reactive substances.

* Corresponding author: Dr Jürgen G. Erhardt, fax +49 711 4593822, email erhardtj@uni-hohenheim.de 
(day 0), after supplementation (day 7) and after the "washout phase' (day 14) blood and buccal mucosal cell samples were taken. The concentration of $\alpha$-tocopherol, $\beta$-carotene, cholesterol and TBARS were determined in the blood samples. The concentration of $\alpha$-tocopherol, $\beta$-carotene, TBARS and DNA were determined in the buccal mucosal cells.

One week prior to supplementation and during the study period (14d) all foods were recorded and analysed with the aid of a nutrition program EBISpro (FEP, Esslingen, Germany) for their content of $\alpha$-tocopherol and $\beta$-carotene.

\section{Sampling of blood and buccal mucosal cells}

Sampling of blood. Blood sampling by skin puncture of the finger was carried out as described recently (Erhardt et al. 1999) using Microtainer, Brand Safety Flow Lancets from Becton Dickinson (Franklin Lakes, NJ, USA). For the collection of blood, Microtainer Brand Plasma Separator Tubes containing lithium heparin from Becton Dickinson were used. After discarding the first drop, more than $400 \mu \mathrm{l}$ blood was collected, the tubes were then centrifuged at $12000 \mathrm{~g}$ for $1 \mathrm{~min}$. The resulting plasma was transferred in 20 and $50 \mu \mathrm{l}$ portions to several Eppendorf Safe Lock $0.5 \mathrm{ml}$ Micro test tubes (Eppendorf, Hamburg, Germany) and frozen at $-80^{\circ} \mathrm{C}$ until analysis, which was completed in less than 2 months.

Sampling of buccal mucosal cells. Buccal mucosal cells were collected by using a non-invasive method established by Gilbert et al. (1990). Initially the subjects rinsed their mouths with water thoroughly and then brushed the inside of their cheeks with a soft toothbrush twenty times on each side. With this procedure, contamination of the buccal mucosal cells with blood could be avoided. After the brushing the subjects were asked to rinse both cheeks with $20 \mathrm{ml} \mathrm{NaCl}$ solution $(9 \mathrm{~g} / \mathrm{l})$ twice and wash the toothbrush with a further $10 \mathrm{ml} \mathrm{NaCl}$ solution $(9 \mathrm{~g} / \mathrm{l})$. The solutions were collected in a 2,6-di-tert-butyl- $p$-hydroxytoluene (BHT)-coated $50 \mathrm{ml}$ tube. Subsequently, the samples were centrifuged at $1400 \mathrm{~g}$ for $10 \mathrm{~min}$ at $4^{\circ} \mathrm{C}$. The supernatant fraction was discarded and $15 \mathrm{ml}$ cold PBS solution was added. The samples were vortexed and centrifuged again at $1400 \mathrm{~g}$ for $5 \mathrm{~min}$. After removal of the supernatant fraction, $300 \mu \mathrm{l}$ cold PBS was added, vortexed and homogenized with a spatula. The cell suspension was then divided into three aliquots for the determination of $\beta$-carotene, $\alpha$-tocopherol, TBARS and DNA and treated as follows. Each sample was pipetted into a BHT-coated microcentrifuge tube and centrifuged at $12000 \mathrm{~g}$ for $1 \mathrm{~min}$. The supernatant fraction was discarded and the cell pellet was flushed with $\mathrm{N}_{2}$ for $20 \mathrm{~s}$; the tube was then sealed and stored at $-80^{\circ} \mathrm{C}$.

\section{Analytical methods}

Measurement of $\alpha$-tocopherol and $\beta$-carotene. The analysis was performed according to Erhardt et al. (1999) using slight modifications.

Sample preparation and determination in plasma. The proteins were denatured by mixing $20 \mu \mathrm{l}$ plasma in a $0.5 \mathrm{ml}$ vessel with $100 \mu \mathrm{l}$ ethanol-butanol $(1: 1, \mathrm{v} / \mathrm{v})$, containing
$5 \mathrm{mg} \mathrm{BHT} / \mathrm{ml}$ and $4 \mu \mathrm{mol}$ tocol/ $/ \mathrm{l}$ as internal standard). Lipophilic vitamins were extracted by vigorous mixing for $10 \mathrm{~s}$. The mixture was then centrifuged for $5 \mathrm{~min}$ at $12000 \mathrm{~g}$ and $30 \mu \mathrm{l}$ supernatant fraction was analysed by using reversed-phase HPLC.

Sample preparation and determination in buccal тисоsal cells. First, the cell pellet was redissolved in $400 \mu \mathrm{l}$ sodium dodecyl sulfate $(10 \mathrm{~g} / \mathrm{l}$, containing $10 \mathrm{ml} / \mathrm{l} \mathrm{BHT/l})$. Saturated $\mathrm{NaCl}$ solution $(20 \mu \mathrm{l})$ was added for improved separation. $\alpha$-tocopherol and $\beta$-carotene were extracted with $2 \times 300 \mu \mathrm{l}$ hexane (containing $5 \mathrm{mg} \mathrm{BHT} / \mathrm{ml}$ ). The combined organic supernatant fractions were evaporated using $\mathrm{N}_{2}$ flow and the residue was redissolved in $100 \mu \mathrm{l}$ ethanol-butanol (1:1, v/v, containing $5 \mathrm{mg}$ BHT/ml and $4 \mu \mathrm{mol} / \mathrm{l}$ Tocol (Matreya Inc., Pleasant Gap, PA, USA) as internal standard). Of each sample, $80 \mu \mathrm{l}$ were analysed by reversed-phase HPLC.

HPLC determination. The HPLC system consisted of the following components: intelligent-pump L6200; UV-VIS Detector L4250 (Merck, Darmstadt, Germany), injection valve (Rheodyne, Rohnert Park, CA, USA); HPLC software (Berthold, Pforzheim, Germany). The UV-VIS spectrophotometer was programmed as follows: $292 \mathrm{~nm}$ from 0 to $4 \mathrm{~min}$ and $450 \mathrm{~nm}$ from 4 to $8 \mathrm{~min}$. A Nucleosil $125 \times 3 \mathrm{~mm}, 100 \mathrm{RP}-18(3 \mu \mathrm{m})$ column from Macherey Nagel (Dueren, Germany) was used. An isocratic mobile phase consisting of acetonitrile-tetrahydrofuranemethanol-ammonium acetate $(10 \mathrm{~g} / \mathrm{l})(684: 220: 68: 28$, by vol.) was used in recirculation mode for approximately 250 samples. The flow rate was maintained at $1 \mathrm{ml} / \mathrm{min}$. For quantification we used the international certified NIST standards (National Institute of Standards and Technology, Gaithersburg, MD, USA).

Measurement of thiobarbituric acid-reactive substances. The analysis was previously described by Jentzsch et al. (1996). For plasma, $50 \mu \mathrm{l}$ was mixed with $3 \mu \mathrm{l} 0 \cdot 1 \mathrm{M}$ BHT in ethanol, $50 \mu \mathrm{l} 0.2 \mathrm{M}$-phosphoric acid and $6 \mu \mathrm{l}$ $0 \cdot 1 \mathrm{M}$-thiobarbituric acid. The mixture was then incubated at $90^{\circ} \mathrm{C}$ for $45 \mathrm{~min}$. The samples were cooled on ice, $125 \mu \mathrm{l}$ butanol and $10 \mu \mathrm{l}$ saturated $\mathrm{NaCl}$ solution were added and the mixture was vortexed for $60 \mathrm{~s}$. After centrifugation (1 min, $12000 \mathrm{~g}$ ) $62.5 \mu \mathrm{l}$ supernatant fraction was measured in a fluorometer $(\lambda 530 \mathrm{~nm}$ excitation, $\lambda$ $590 \mathrm{~nm}$ emission).

Buccal mucosal cells. The cell pellet was mixed with $10 \mu \mathrm{l}$ BHT in $0 \cdot 1 \mathrm{M}$-ethanol and $200 \mu \mathrm{l} 0 \cdot 2 \mathrm{M}$-phosphoric acid and $25 \mu \mathrm{l} 0 \cdot 1 \mathrm{M}$-thiobarbituric acid. The mixture was then incubated at $90^{\circ} \mathrm{C}$ for $45 \mathrm{~min}$. The samples were cooled on ice, and $500 \mu \mathrm{l} \mathrm{Butanol}$ and $50 \mu \mathrm{l}$ saturated $\mathrm{NaCl}$ were added and the mixture was vortexed for $60 \mathrm{~s}$. After centrifugation $(1 \mathrm{~min}, 12000 \mathrm{~g}) 250 \mu \mathrm{l}$ supernatant fraction was analysed in a fluorometer $(\lambda$ $530 \mathrm{~nm}$ excitation, $\lambda 590 \mathrm{~nm}$ emission). For quantification malonaldehyde-bis(dimethyl acetate) in phosphoric acid was used.

Measurement of DNA in buccal mucosal cells. A method according to Natarajan et al. (1994) was used. The cell pellet was mixed and incubated for $24 \mathrm{~h}$ at $37^{\circ} \mathrm{C}$ with $200 \mu \mathrm{l}$ acetaldehyde in perchloric acid $(160 \mathrm{~g} / \mathrm{l})$ and $320 \mu \mathrm{l}$ diphenylamine in acetic acid $(40 \mathrm{ml} / \mathrm{l})$. After centrifugation, $200 \mu$ l supernatant fraction was analysed at $\lambda$ 
$750 \mathrm{~nm}$ in a microtitre plate reader. For quantification a standard DNA from herring sperm was used.

Measurement of cholesterol. The analysis was performed as previously described (Erhardt et al. 1999) by a standard clinical chemistry method.

\section{Statistical evaluation}

The data were analysed using the software SPSS for Windows (version 8.0; SPSS Inc., Chicago, IL, USA). For the comparison of days 0,7 and 14 the Wilcoxon matched pairs test was used, a $P$ value of $<0.05$ was assumed to be significant.

\section{Ethical considerations}

The individuals provided informed consent and the study was performed in accord with the 1983 revision of the Helsinki Declaration. The study was approved by the Ethical Committee of the Landesärztekammer/Stuttgart, Germany.

\section{Results}

Fig. 1 demonstrates a significant increase of $\beta$-carotene and $\alpha$-tocopherol concentration in plasma in the first $7 \mathrm{~d}$. After the following $7 \mathrm{~d}$ of the wash-out phase (days 7-14), the vitamin levels decreased significantly but they still showed a significant higher level compared with day 0 . In buccal mucosal cells a significant increase could be detected only for $\beta$-carotene concentration as shown in Fig. 2. A significant peak level $(P<0.05)$ was determined at day 14. This is in contrast to the situation in plasma where $\beta$-carotene level had decreased between days 7 and 14 . There was only a marginal increase in the concentration of $\alpha$-tocopherol ( $P=0 \cdot 07)$ following $7 \mathrm{~d}$ supplementation. On day $14 \alpha$-tocopherol concentration in buccal mucosal cells had reached nearly the basal level of day 0 .

The TBARS method was applied to assess the oxidative stress in plasma and in buccal mucosal cells. In the present
Table 1. Dietary intake of $\alpha$-tocopherol and $\beta$-carotene of the twelve subjects during the three study periods

(Mean values and standard deviations)

\begin{tabular}{|c|c|c|c|c|c|c|}
\hline & \multicolumn{2}{|c|}{$\begin{array}{l}1 \text { week } \\
\text { prior to } \\
\text { study }\end{array}$} & \multicolumn{2}{|c|}{$\begin{array}{l}\text { During } \\
\text { supplemen- } \\
\text { tation }\end{array}$} & \multicolumn{2}{|c|}{$\begin{array}{l}\text { Wash-out } \\
\text { period }\end{array}$} \\
\hline & Mean & SD & Mean & SD & Mean & SD \\
\hline$\beta$-Carotene $(\mathrm{mg} / \mathrm{d})$ & $3 \cdot 1$ & $2 \cdot 0$ & 3.7 & $1 \cdot 6$ & 3.7 & $2 \cdot 3$ \\
\hline$\alpha$-Tocopherol $(\mathrm{mg} / \mathrm{d})$ & $16 \cdot 2$ & $4 \cdot 0$ & $15 \cdot 2$ & $6 \cdot 0$ & 14.9 & 4.4 \\
\hline
\end{tabular}

study, an inverse correlation was found between increasing levels of $\beta$-carotene and a significant decrease of TBARS in buccal mucosal cells as shown in Fig. 3. TBARS levels in plasma were slighty reduced, but no significant difference could be determined.

The food analysis shown in Table 1 demonstrates that the daily intake of $\alpha$-tocopherol and $\beta$-carotene integrated in food contributed approximately $10-15 \%$ of the supplemented dose of the administered vitamins. No significant differences in the intake of food by the subjects between the three periods were found (Table 1).

\section{Discussion}

In recent years, several studies have been published concerning buccal mucosal cells as an indicator for the nutritional status (Badcock \& Pinnock, 1990; Gilbert et al. 1990; Kaempf et al. 1994; Liede et al. 1998; Newcomb et al. 1990; Peng \& Peng, 1992; Peng et al. 1993, 1994, 1995; Stich et al. 1986). Gilbert et al. (1990) as well as Newcomb et al. (1990) showed a large inter-individual variability, which indicates a dependency between the intake of $\beta$-carotene and the resulting concentration of $\beta$ carotene in buccal mucosal cells. Factors such as smoking or a lower resorption rate in low responders additionally contribute to these effects. In contrast, intra-individual

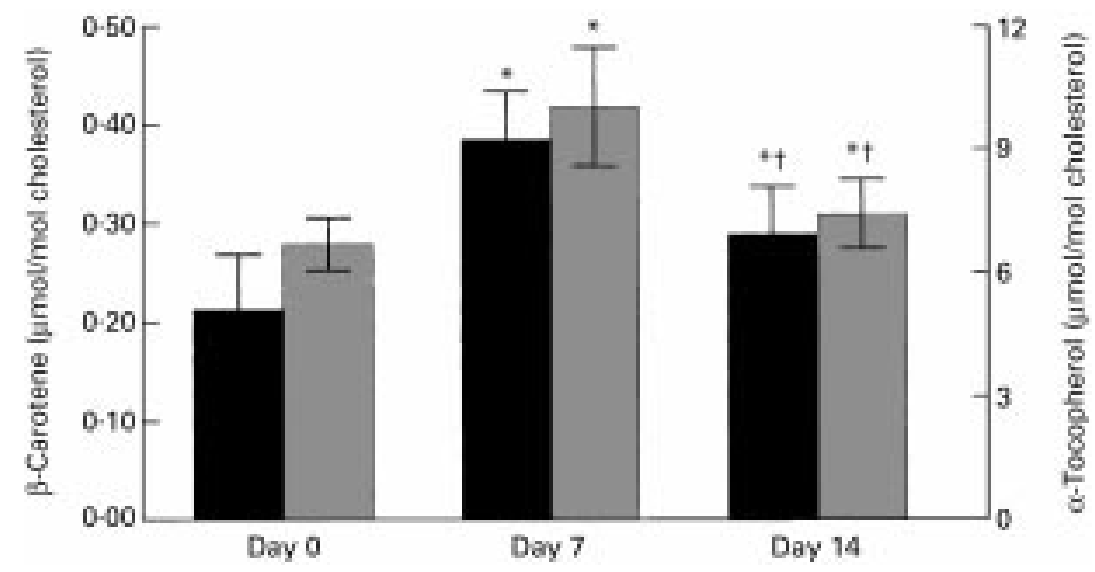

Fig. 1. Plasma level of $\beta$-carotene and $\alpha$-tocopherol before (day 0 ), after supplementation (day 7) and after the wash-out period (day 14) in twelve subjects. For details of subjects and procedures, see p. 472. $\mathbf{\square}, \beta$-carotene; $\square, \alpha$-tocopherol. Values are means with standard deviations shown by vertical bars. Mean values were significantly different from those at day $0:{ }^{\star} P<0.05$. Mean values were significantly different from those at day $7: \dagger P<0.05$. 


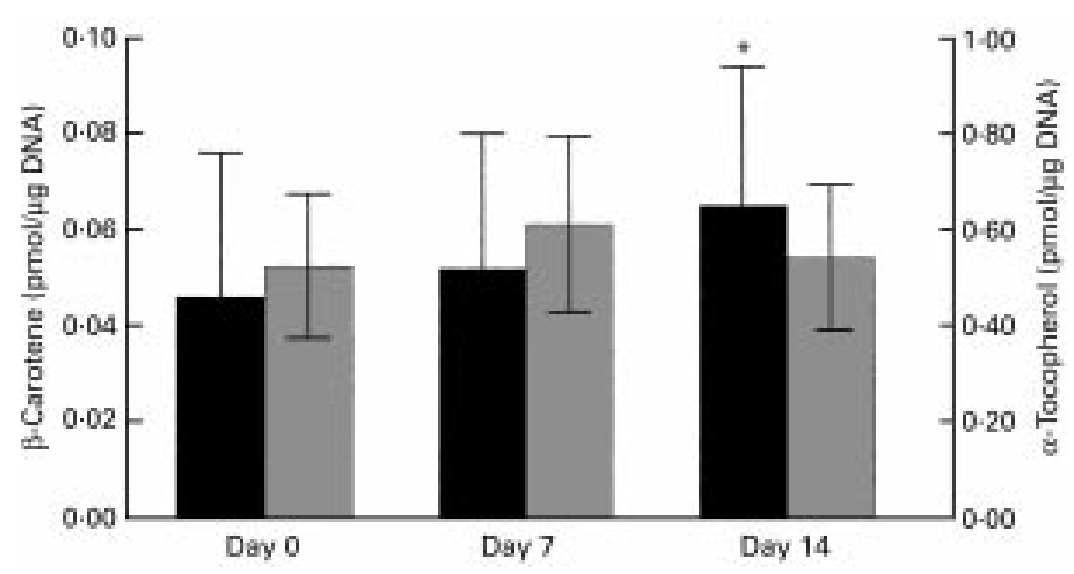

Fig. 2. Concentration of $\beta$-carotene and $\alpha$-tocopherol in buccal mucosal cells before (day 0), after supplementation (day 7) and after the wash-out period (day 14) in twelve subjects. For details of subjects and procedures, see p. 472. $\mathbf{\square}, \beta$-carotene; $\square, \alpha$-tocopherol. Values are means with standard deviations shown by vertical bars. Mean value was significantly different from those at day 0 and day 7 : ${ }^{\star} P<0.05$.

variability is small, making such a measurement suitable for evaluating the nutritional status (Peng et al. 1994).

The results of our present study showed an increase of $\beta$-carotene in plasma and buccal mucosal cells of each volunteer during supplementation. Remarkably, an increase of $\beta$-carotene in buccal mucosal cells could still be detected on day 14 , after the wash-out phase. This can be explained by the fact that buccal mucosal cells which have accumulated the supplemented $\beta$-carotene need about $7 \mathrm{~d}$ to mature and move to the surface of the buccal mucosa. These results are in accordance with Prince \& Frisoli (1993) who found an accumulation of $\beta$-carotene in the skin 2 weeks after supplementation.

In plasma the increase of the $\alpha$-tocopherol level was comparable with the $\beta$-carotene-level; however, in buccal mucosal cells there was no significant increase from day 0 to day 7 or day 14. Different transport mechanisms compared with $\beta$-carotene, a possibly low dose of $\alpha$-tocopherol or interactions between the two substances could be regarded as an explanation. For example Xu et al. (1992) demonstrated a decrease of $\alpha$-tocopherol in plasma and skin after long-term supplementation with $\beta$-carotene.

As plasma values of $\beta$-carotene and $\alpha$-tocopherol showed a rapid increase following supplementation and a sharp decrease after cessation of supplementation a good compliance by the volunteers could be assumed.

The oxidative stress of buccal mucosal cells and plasma was evaluated by the TBARS method. Our present study showed a significant decrease in TBARS in buccal mucosal cells between day 0 (start of supplementation) and day 14 (after the wash-out period). No significant variation with respect to TBARS was detected in plasma, in spite of higher variations in the concentration of antioxidants. It might be that blood antioxidants such as uric acid compensated for oxidative effects in the plasma of healthy volunteers in our short-term application (Nieto et al. 2000).

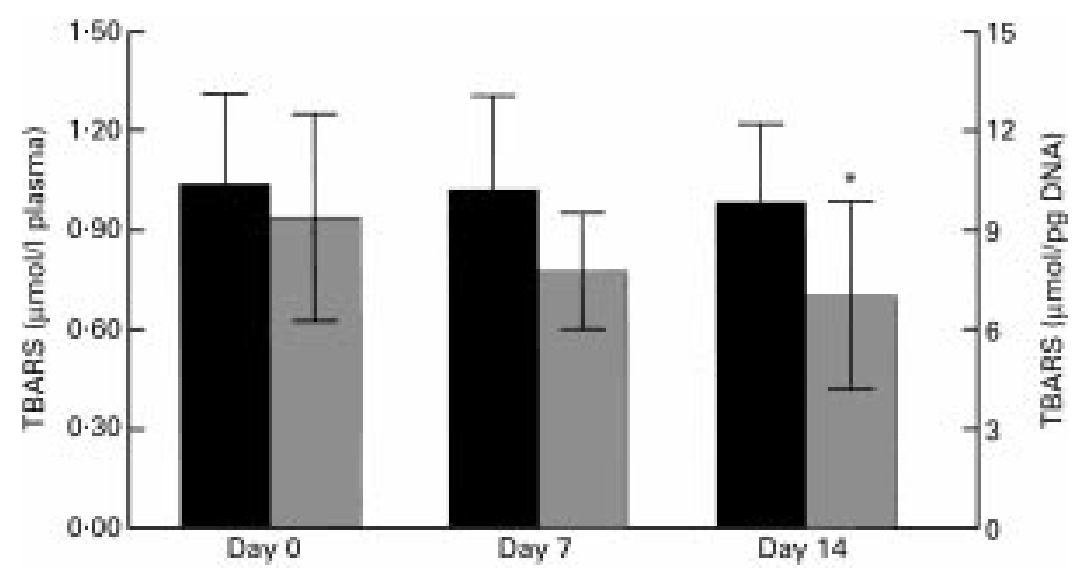

Fig. 3. Thiobarbituric acid-reactive substances (TBARS) in plasma and buccal mucosal cells before (day 0), after supplementation (day 7) and after the wash-out period (day 14) in twelve subjects. For details of subjects and procedures, see p. 472 . $\mathbf{\square}$, Plasma; n, buccal mucosal cells. Values are means with standard deviations shown by vertical bars. Mean value was significantly different from those at day 0 : ${ }^{*} P<0.05$. 
Several limitations regarding the measurement of TBARS have been reported (Janero, 1990), thus placing the physiological relevance of such measurements in doubt. However, in comparison with other studies we used a modified TBARS test (Jentzsch et al. 1996), which circumvents the formation of malondialdehyde during the incubation. With this modified test, Frank et al. (1998) have shown satisfying correlations of TBARS in cells and other variables for oxidative stress (like oxidative modifications of lipids and proteins detected by immunohistochemical methods). Because of a low amount of available cells, it was not possible to apply these methods in the present study.

In conclusion, supplementation with $\beta$-carotene and $\alpha$ tocopherol causes a significant increase in the concentration of these antioxidants in plasma and partly in buccal mucosal cells, however, a possibly more important effect could be the reduced production of TBARS in the buccal mucosal cells. Hence, the measurement of oxidative stress via easily obtainable cells, e.g. buccal mucosal cells, may provide an accurate and easily available indication of oxidative stress in target tissues of an organism.

\section{Acknowledgements}

This work was supported by funds from the Institut Danone für Ernährung e.V., München/Germany.

\section{References}

Badcock N \& Pinnock C (1990) The determination of vitamin E in buccal mucosal cells. International Journal of Vitamin and Nutrition Research 60, 298-299.

Barth TJ, Zöller J, Kübler A, Born IA \& Osswald H (1997) Redifferentiation of oral dysplastic mucosa by the application of the antioxidants $\beta$-carotene, $\alpha$-tocopherol and vitamin $C$. International Journal of Vitamin and Nutrition Research 67, $368-376$.

Erhardt JG, Heinrich F \& Biesalski HK (1999) Determination of retinol and antioxidant vitamins and homocysteine in skin puncture blood. International Journal of Vitamin and Nutrition Research 69, 309-314.

Frank J, Keller DK, Pompella A, Thews O, Biesalski HK \& Vaupel P (1998) Enhancement of oxidative cell injury and antitumor effects of localized $44^{\circ} \mathrm{C}$ hyperthermia upon combination with respiratory hyperoxia and xanthine oxidase. Cancer Research 58, 2693-2698.

Gabriele S, Alberto P, Sergio G, Fernanda F \& Marco MC (2000) Emerging potentials for an antioxidant therapy as a new approach to the treatment of systemic sclerosis. Toxicology 30, $1-15$.

Garewal HS, Meyskens FL Jr, Killen D, Reeves S, Kiersch TA, Elletson H, Strosberg A, King D \& Steinbrann K (1990) Response of oral leukoplasia to beta-carotene. Journal of Clinical Oncology 8, 1715-1720.

Gilbert AM, Stich HF, Rosin MP \& Davison AJ (1990) Variations in the uptake of beta-carotene in the oral mucosa of individuals after 3 days of supplementation. International Journal of Cancer 45, 855-859.

Janero DR (1990) Malondialdehyde and thiobarbituric acid- reactivity as diagnostic indices of lipid peroxidation and peroxidative tissue injury. Free Radical Biology and Medicine 9, $515-540$.

Jentzsch AM, Fürst P \& Biesalski HK (1996) Improved analysis of malondialdehyde in human body fluids. Free Radical Biology and Medicine 20, 251-256.

Kaempf DE, Miki M, Ogihara T, Okamoto R, Konishi K \& Mino M (1994) Assessment of vitamin E nutritional status in neonates, infants and children - on the basis of $\alpha$-tocopherol levels in blood components and buccal mucosal cells. International Journal of Vitamin and Nutrition Research 64, $185-191$.

Liede KE, Alfthan G, Hietanen JH, Haukka JK, Saxen LM \& Heinonen OA (1998) Beta-carotene concentration in buccal mucosal cells with and without dysplastic oral leukoplasia after long-term beta-carotene supplementation in male smokers. European Journal of Clinical Nutrition 52, 872-876.

Natarajan N, Shambaugh GE, Elseth KM, Haines GK \& Radosevich JA (1994) Adaptation of the diphenylamine (DPA) assay to a 96-well plate tissue culture format and comparison with the MTT assay. Biotechniques 17, 166-171.

Newcomb SA, Culling-Berglund AJ \& Davis TP (1990) Endogenous levels of $\beta$-carotene in human buccal mucosa cells by reversed-phase high-performance liquid chromatography. Journal of Chromatography 526, 47-58.

Nieto FJ, Iribarren C, Gross MD, Comstock GW \& Cutler RG (2000) Uric acid and serum antioxidant capacity: a reaction to atherosclerosis? Atherosclerosis 148, 131-139.

Peng YS \& Peng YM (1992) Simultaneous liquid chromatographic determination of carotenoids, retinoids, and tocopherols in human buccal mucosal cells. Cancer Epidemiology, Biomarkers and Prevention 1, 375-382.

Peng YM, Peng YS \& Lin Y (1993) A nonsaponification method for the determination of carotenoids, retinoids, and tocopherols in solid human tissues. Cancer Epidemiology, Biomarkers and Prevention 2, 139-144.

Peng YM, Peng YS, Lin Y, Moon T, Roe DJ \& Ritenbaugh C (1995) Concentrations and plasma-tissue-diet relationships of carotenoids, retinoids, and tocopherols in humans. Nutrition and Cancer 23, 233-245.

Peng YS, Peng YM, McGee DL \& Alberts DS (1994) Carotenoids, tocopherols, and retinoids in human buccal mucosal cells: intra and interindividual variability and storage stability. American Journal of Clinical Nutrition 59, 636-643.

Prince MR \& Frisoli JK (1993) $\alpha$-Carotene accumulation in serum and skin. American Jouranl of Clinical Nutrition 57, $175-181$.

Stich HF, Hornby AP \& Dunn BP (1986) Beta-carotene levels in exfoliated human mucosa cells following its oral administration. Cancer Letters 30, 133-141.

Stich HF, Rosin MP, Hornby AP, Mathew B, Sankaranarayanan R \& Nair MK (1988) Remission of oral leukoplasias and micronuclei in tobacco/betel quid chewers treated with beta-carotene and with beta-carotene plus vitamin A. International Journal of Cancer 42, 195-199.

Toma S, Benso S, Albanese E, Palumbo R, Cantoni E, Nicolo G \& Mangiante P (1992) Treatment of oral leukoplasia with betacarotene. Oncology 49, 77-81.

Xu MJ, Plezia PM, Albert DS, Emerson SS, Peng YM, Sayer SM, Lin Y, Ritenbaugh C \& Gensler HL (1992) Reduction in plasma or skin $\alpha$-tocopherol concentration with long-term oral administration of $\beta$-carotene in human and mice. Journal of the National Cancer Institute 84, 1559-1565. 